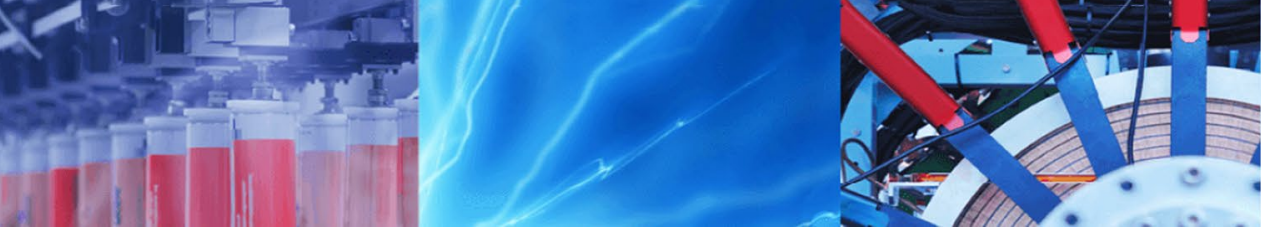

Research Article

\title{
Perrhenate sodalite growth from alkali silicate melts by noble metal catalysis
}

\author{
Michael Anenburg ${ }^{1}$ (D) Charles Le Losq ${ }^{1}$ (i)
}

(c) Springer Nature Switzerland AG 2019

\begin{abstract}
Perrhenate sodalite $\left(\mathrm{Na}_{8} \mathrm{Al}_{6} \mathrm{Si}_{6} \mathrm{Re}_{2} \mathrm{O}_{32}\right)$ which contains the perrhenate anion $\left(\mathrm{ReO}_{4}^{-}\right)$has been synthesised in equilibrium with $\mathrm{Na}-\mathrm{Fe}$-rich aluminosilicate melt and Re metal at $1100^{\circ} \mathrm{C}$ and $500 \mathrm{MPa}$. Quenched glasses contain a homogeneous distribution of nepheline and magnetite, whereas sodalite only forms a crust on noble metal surfaces (Pt, Pt-Rh, Ag-Pd, and $\mathrm{Re}$ ) in contact with the glass. The sodalite have been characterised by wavelength-dispersive $\mathrm{X}$-ray spectroscopy and Raman spectroscopy. The experimental products contain both $\operatorname{Re}(0)$ and $\operatorname{Re}(\mathrm{VII})$, but other oxidation states of Re were not detected, suggesting the role of $\mathrm{Na}$ as a higher oxidation state stabiliser. Sodalite has potential uses for immobilising volatile Re and Tc during nuclear waste vitrification. Our study demonstrates the thermodynamic stability of perrhenate sodalite at Na-rich aluminosilicate melts at high temperature and pressure conditions.
\end{abstract}

Keywords Pertechnetate $\cdot$ Microporous $\cdot$ Mesoporous $\cdot$ Zeolite $\cdot$ Experimental petrology $\cdot$ Optical basicity

\section{Introduction}

Sodalite is a naturally occurring feldspathoid mineral with the formula $\mathrm{Na}_{8} \mathrm{Al}_{6} \mathrm{Si}_{6} \mathrm{O}_{24} \mathrm{Cl}_{2}$, in which $\mathrm{Si}$, $\mathrm{Al}$ and $\mathrm{Na}$ form a cage structure containing chloride anions [1,2]. Sodalite anion chemistry is flexible due to the relatively large cage structure, and compounds incorporating halides (e.g., bromide and iodide) and oxyanions (e.g., tungstate, molybdate, permanganate, chlorate, perchlorate, nitrate, etc.) have been synthesised [3-11]. In particular, incorporation of perrhenate $\left(\mathrm{ReO}_{4}^{-}\right)$to the sodalite cage structure has been the focus of several studies due to its similarity to pertechnetate $\left(\mathrm{TcO}_{4}{ }^{-}\right)$and applications in nuclear waste management [12-17]. Synthesis of perrhenate sodalite (referred to as Re-sodalite hereafter) has been achieved via a low temperature hydrothermal process $\left(175^{\circ} \mathrm{C}\right)$ involving preliminary solution chemistry methods [12-17]. Additionally, Re-sodalite has been shown to be stable in high temperature melts and retain its Re content [15]. This raises the possibility that Re-sodalite can crystallise directly from silicate melts, without an intermediate stage of low temperature solution and hydrothermal synthesis. As stabilisation of nuclear waste is done in glass matrices, improving incorporation of volatile Tc through optimisation of the glass composition and formation process is an important goal, for which Re has been proposed as an analogue [18-21]. Determining the conditions that favour the nucleation and growth of Re-sodalite crystals in silicate melts helps in this regard.

In this study we report high temperature and pressure experiments during which we observed crystallisation of Re-bearing sodalite directly from Na-rich silicate melts. The experiments were conducted at high pressure in order to avoid the problems of Re volatilisation from the silicate glass.

Michael Anenburg, michael.anenburg@anu.edu.au| ${ }^{1}$ Research School of Earth Sciences, Australian National University, Acton, ACT 2601, Australia.

SN Applied Sciences (2019) 1:372 | https://doi.org/10.1007/s42452-019-0414-7 


\section{Experimental methods}

Experimental details have been described in detail elsewhere [22]. In short, a silicate starting material was prepared by mixing sodium metasilicate $\left(\mathrm{Na}_{2} \mathrm{SiO}_{3}\right)$, silica $\left(\mathrm{SiO}_{2}\right)$, hematite $\left(\mathrm{Fe}_{2} \mathrm{O}_{3}\right)$ and alumina $\left(\mathrm{Al}_{2} \mathrm{O}_{3}\right)$ in an agate mortar and pestle. The mixture was sintered and partly vitrified at $800{ }^{\circ} \mathrm{C}$ to produce a homogenous semi-glassy material containing 47.16 wt $\% \mathrm{SiO}_{2}, 17.62$ wt $\% \mathrm{Na}_{2} \mathrm{O}$, $17.94 \mathrm{wt} \% \mathrm{Al}_{2} \mathrm{O}_{3}$ and $17.28 \mathrm{wt} \% \mathrm{Fe}_{2} \mathrm{O}_{3}$, corresponding to a 50:50 stoichiometric mixture of nepheline $\left(\mathrm{NaAlSiO}_{4}\right)$ and aegirine $\left(\mathrm{NaFeSi}_{2} \mathrm{O}_{6}\right)$.

The silicate mix was loaded into a $2.3 \varnothing \mathrm{mm}$ noble metal capsule (either $\mathrm{Ag}-\mathrm{Pd}$ alloy or $\mathrm{Pt}$ ) together with a piece of $\mathrm{Pt}_{94-70}-\mathrm{Rh}_{6-30}$ alloy and a Re strip. The capsules were then loaded into a $1 / 2$-inch $(12.7 \mathrm{~mm})$ pressure vessel via a MgO-graphite-Pyrex-NaCl-Teflon assembly. The pressure vessel was inserted into a 200-ton piston cylinder apparatus, in which pressure and temperature were increased simultaneously to run conditions. Three experiments were conducted, the details of which are given in Table 1. The experiments were quenched after the run duration, reaching room temperature in about $20 \mathrm{~s}$. Temperature measurement was precise to $2{ }^{\circ} \mathrm{C}$ and pressure to less than $50 \mathrm{MPa}$.

After each experiment, the assembly was mounted in epoxy, and polished using sand paper to expose the interior of the noble metal capsule. The surface was then polished using diamond paste to prepare the samples for analysis.

\section{Analytical methods}

Backscattered electron (BSE) images, X-ray spectra scans, and quantitative compositions were acquired using a JEOL 8530F Plus electron probe microanalyser (EPMA) running with an accelerating voltage of $15 \mathrm{kV}$. X-ray scans were conducted using wavelength-dispersive spectrometers (WDS) with TAP (thallium acid phthalate), PET (pentaerythritol) and LIF (lithium fluoride) diffracting crystals, a $100 \mathrm{nA}$ beam current, and a $5 \mu \mathrm{m}$ defocused beam $[23,24]$.

Table 1 Experimental details

\begin{tabular}{|c|c|c|c|}
\hline Experiment & Pressure (MPa) & $\begin{array}{l}\text { Temperature and } \\
\text { time }\end{array}$ & Capsule material \\
\hline D1900-101 & 500 & $19 \mathrm{~h}$ at $1100^{\circ} \mathrm{C}$ & $\mathrm{Ag}_{50} \mathrm{Pd}_{50}$ \\
\hline D1901-102 & 500 & $\begin{array}{l}13 \mathrm{~h} \text { at } 1100^{\circ} \mathrm{C} \text {, } \\
13 \mathrm{~h} \mathrm{ramp} \text { to } \\
900^{\circ} \mathrm{C}\end{array}$ & $\mathrm{Pt}$ \\
\hline D1906-103 & 500 & $19 \mathrm{~h}$ at $1100^{\circ} \mathrm{C}$ & Pt \\
\hline
\end{tabular}

Quantitative analyses were conducted using a $2 \mathrm{nA}$ beam current with the following reference materials: albite $(\mathrm{Na}$, $\mathrm{Al}, \mathrm{Si})$, hematite ( $\mathrm{Fe})$, Re metal $(\mathrm{Re})$. The beam was defocused to $30 \mu \mathrm{m}$ when analysing the silicate glass to avoid Na-migration under the beam.

For chemical analysis of Re-bearing silicates, WDS methods have an advantage over EDS (energy-dispersive spectroscopy) because of the Re M-lines interferences on the Si K-line, introducing uncertainties in the quantified composition. The higher energy resolution of WDS relative to EDS allows the overlap to be eliminated.

Raman spectra were recorded using a Renishaw InVia spectrometer, equipped with a Peltier-cooled detector, a $2400 \mathrm{l} / \mathrm{mm}$ grating and a confocal system. Samples were excited using a $532 \mathrm{~nm}$ laser line focused on sample surface using $a \times 50$ Leica objective. The laser power on the sample was $\sim 1.2 \mathrm{~mW}$. The spatial resolution was $\sim 1 \mu \mathrm{m}$, and the spectral resolution $\sim 1.2 \mathrm{~cm}^{-1}$. Raman spectra were processed with using the rampy library [25] in the programming language Python. Water contents of the glasses were determined using two independently established methods [26, 27]. Both methods returned consistent values, within error.

\section{Results}

All experiments resulted in a homogenous silicate glass with abundant dispersed crystals of magnetite and noble metal nanoparticles (Fig. 1). See [22] for a discussion of the nanoparticle significance. Crystals of Na-perrhenate $\left(\mathrm{NaReO}_{4}\right)$ and a Re-chloride phase of uncertain composition grew on the polished sample surface, particularly where pitted by scratches or imperfect polishing (Fig. 1b). Rare crystals of nepheline occur in experiments D1900-101 and D1906-103, whereas nepheline is abundant in experiment D1901-102 due to the lower run temperature. Rarely, Al-Fe spinel inclusions occur inside nepheline (Fig. 1c). We suspect it to be an unreacted relict from the sintered starting materials.

A crust of sodalite, 1-10 $\mu \mathrm{m}$ thick, formed on all noble metal surfaces present inside the capsule (Fig. 1). This includes the capsule itself, the Pt-Rh alloy and the Re strip. A gap exists between the glass and sodalite and the metal surface (now filled with epoxy resin), probably due to thermal contraction during quenching (Fig. 1c).

A WDS scan of a sodalite crystal from experiment D1906-103 shows that it contains $\mathrm{Na}, \mathrm{Al}, \mathrm{Fe}, \mathrm{Si}$ and $\mathrm{Re}$ (Fig. 2). Spectra of other experiments are similar and not shown here. The height of the Na peak is abnormally low. This can be explained by the mobility of $\mathrm{Na}$ under the electron beam, causing significant migration during the 30-min scan duration [28]. Quantitative chemical 
a
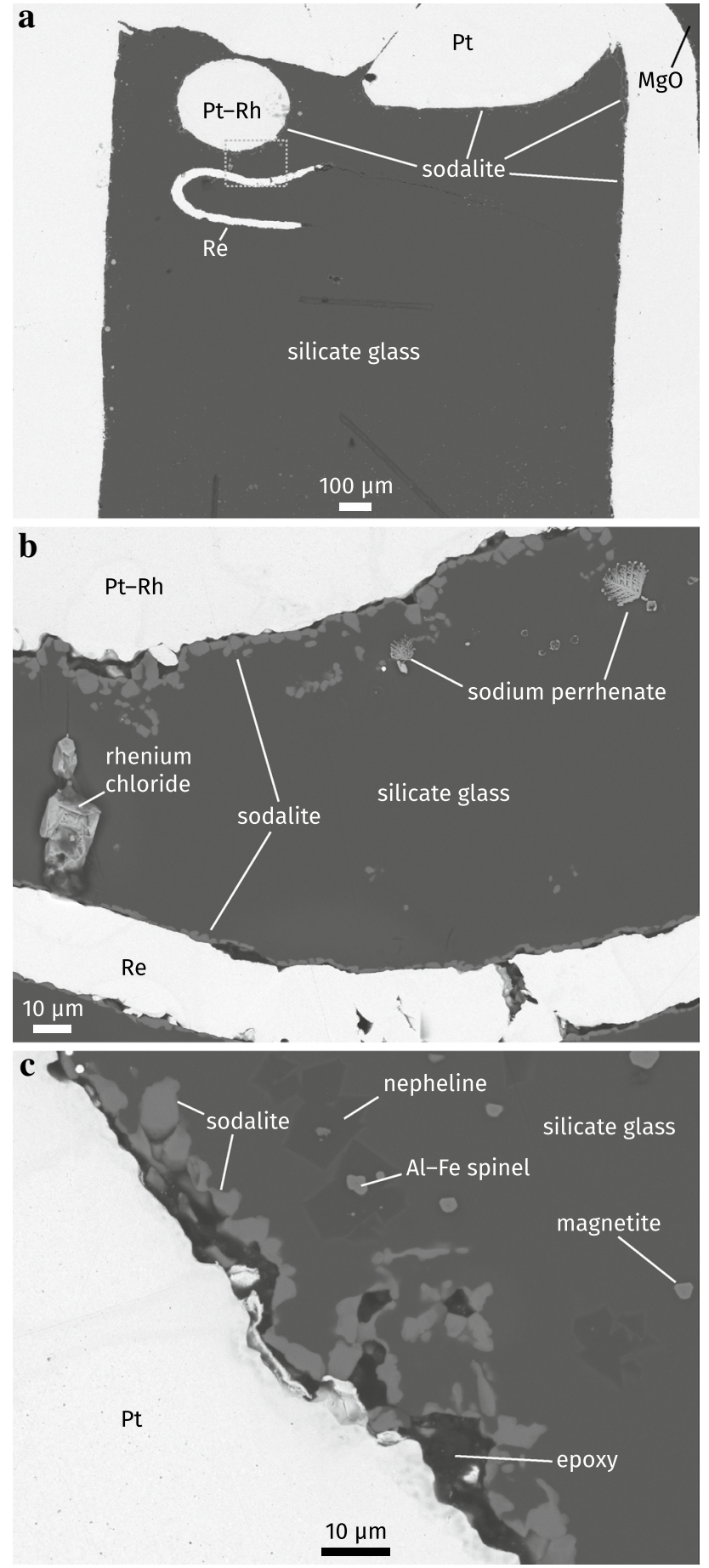

Fig. 1 Backscattered electron images of experiment D1906-103. Dashed grey outline in a marks location of $\mathbf{b}$

compositions of sodalite and silicate glass are given in Tables 2 and 3, respectively. The measured sodalite composition approximates that of stoichiometric Re-sodalite $\left(\mathrm{Na}_{8} \mathrm{Al}_{6} \mathrm{Si}_{6} \mathrm{Re}_{2} \mathrm{O}_{32}\right)$, with several minor differences. Re contents are consistently below 2 atoms per formula unit, suggesting that the cages are not fully occupied by perrhenate anions. Alternatively, as perrhenate is moderately volatile, it could have been mobilised under the electron beam. This could lead to an overestimation of the other calculated cation values as they are calculated assuming full occupancy and 32 oxygens. Contents of Si are consistently above 6 , and it is not clear whether it results from the overestimation or whether it is real. Natural sodalites commonly contain greater than $6 \mathrm{Si}$ atoms per formula unit [28-30], suggesting that our measured overoccupancy is real. It is possible that the excess $\mathrm{Si}$ is charge balanced by introduction of some divalent $\mathrm{Fe}$ via $2 \mathrm{Al}^{3+} \rightarrow \mathrm{Fe}^{2+}+\mathrm{Si}^{4+}$, both occupying the Al tetrahedral site $[28,29]$. This is consistent with the low Al contents in our samples ( $<6$ atoms per formula units). The low $\mathrm{Al}$ contents could also be explained by trivalent Fe substituting $\mathrm{Al}$ in the crystals ( $\left.\mathrm{Al}^{3+} \rightarrow \mathrm{Fe}^{3+}[29]\right)$. Similarly, $\mathrm{Na}$ contents are occasionally low $(<8)$, which could either result from Na mobility, or alternatively from the chargebalanced simultaneous $\mathrm{Na}^{+}$and $\mathrm{ReO}_{4}{ }^{-}$vacancies in the crystal structure.

Our starting materials included $\mathrm{Fe}^{3+}$, imposing initially oxidised conditions, but Re metal remained in the experimental products, indicating overall reducing conditions during the run durations. There is no other reductant other than metallic Re to drive further reduction, indicating that the oxygen fugacity was buffered to values below but probably close to those determined by the $\mathrm{Re}-\mathrm{ReO}_{2}$ equilibrium [31]. Rhenium contents of the silicate glass are too low to be reliably analysed by EPMA (see Table 3), but are likely to be at a maximum on the order of magnitude of $1000-2000 \mu \mathrm{g} / \mathrm{g}$. These values are within the range expected for silicate melts at this oxygen fugacity [32,33].

Raman spectra of the glasses (Fig. 3a) show typical spectra of sodic Fe-bearing aluminosilicate glasses characterised by two broad peaks near 500 and $1000 \mathrm{~cm}^{-1}$, due to intertetrahedral T-O-T vibrations and intratetrahedral $\mathrm{T}-\mathrm{O}$ stretching vibrations in the glass structure $(\mathrm{T}=\mathrm{Si}, \mathrm{Al}$, $\mathrm{Fe}^{3+}$ ), respectively (see [34] for a review and references cited therein). A small asymmetric peak, centred near $3590 \mathrm{~cm}^{-1}$, is also observed and testifies for a small quantity of water dissolved in the glass. Quantification of its amounts from the Raman spectra yields a mean value of $w t \% \mathrm{H}_{2} \mathrm{O}=0.36 \pm 0.11(1 \sigma)$. This is consistent with the totals obtained from EPMA analysis (Table 3 ).

Raman spectra of the sodalite crystals show three peaks at 332,922 and $976 \mathrm{~cm}^{-1}$, and another peak near $422 \mathrm{~cm}^{-1}$ (Fig. 3b). Those observations are in perfect agreement with previously reported Re-sodalite Raman spectra [16]. The peaks are assigned to vibrational modes of Re in tetragonal coordination [16]; the $332 \mathrm{~cm}^{-1}$ peak is assigned to a pure bending mode $\left(v_{2}\right)$, the $922 \mathrm{~cm}^{-1}$ to an asymmetric stretch mode $\left(v_{3}\right)$, the $976 \mathrm{~cm}^{-1}$ to a symmetric stretch mode $\left(v_{1}\right)$ and the $422 \mathrm{~cm}^{-1}$ peak to a combination of stretching and 


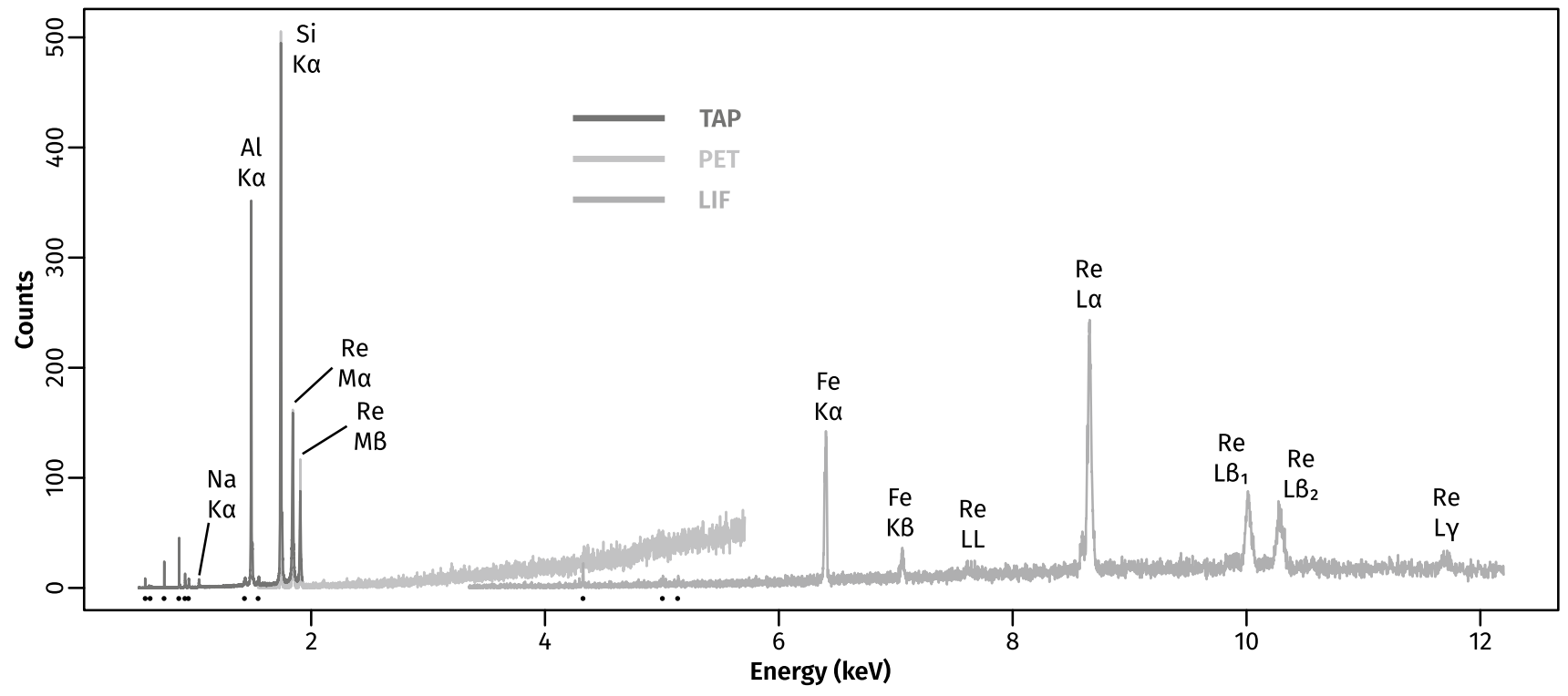

Fig. 2 WDS spectrum of a Re-sodalite crystal in experiment D1906-103

Table 2 Chemical composition of sodalites in oxide wt\%. Atomic proportions calculated based on 32 oxygens

\begin{tabular}{lccccc}
\hline & D1900-101 (1) & D1900-101 (2) & D1900-101 (3) & D1901-102 & D1906-103 \\
\hline $\mathrm{SiO}_{2}$ & 25.40 & 25.39 & 26.87 & 26.09 & 24.01 \\
$\mathrm{Al}_{2} \mathrm{O}_{3}$ & 19.88 & 20.05 & 19.12 & 19.01 & 18.78 \\
$\mathrm{Fe}_{2} \mathrm{O}_{3}$ & 2.60 & 2.36 & 3.11 & 2.31 & 1.79 \\
$\mathrm{Na}_{2} \mathrm{O}$ & 16.05 & 15.06 & 16.42 & 17.42 & 16.37 \\
$\mathrm{Re}_{2} \mathrm{O}_{7}$ & 33.37 & 33.83 & 31.76 & 32.33 & 32.25 \\
$\mathrm{Totals}$ & 97.30 & 96.69 & 97.28 & 97.16 & 93.20 \\
$\mathrm{Si}$ & 6.15 & 6.18 & 6.44 & 6.32 & 6.18 \\
$\mathrm{Al}$ & 5.67 & 5.76 & 5.40 & 5.43 & 5.70 \\
$\mathrm{Fe}$ & 0.47 & 0.43 & 0.56 & 0.42 & 0.35 \\
$\mathrm{Na}$ & 7.53 & 7.11 & 7.64 & 8.18 & 8.17 \\
$\mathrm{Re}$ & 1.92 & 1.94 & 1.82 & 1.86 & 1.85 \\
$\mathrm{Cations}$ & 21.74 & 21.42 & 21.86 & 22.20 & 22.25 \\
\hline
\end{tabular}

Table 3 Chemical composition of silicate glasses in oxide wt $\%$

\begin{tabular}{|c|c|c|c|c|c|c|}
\hline & \multicolumn{2}{|c|}{$101(n=10)$} & \multicolumn{2}{|c|}{$102(n=8)$} & \multicolumn{2}{|c|}{$103(n=10)$} \\
\hline & Mean & SD & Mean & SD & Mean & SD \\
\hline $\mathrm{SiO}_{2}$ & 49.81 & 0.36 & 54.47 & 0.56 & 48.84 & 1.40 \\
\hline $\mathrm{Al}_{2} \mathrm{O}_{3}$ & 18.40 & 0.21 & 14.17 & 0.65 & 17.50 & 0.76 \\
\hline $\mathrm{Fe}_{2} \mathrm{O}_{3}$ & 13.72 & 0.31 & 13.39 & 0.90 & 13.07 & 0.76 \\
\hline $\mathrm{Na}_{2} \mathrm{O}$ & 17.90 & 0.20 & 17.58 & 0.47 & 19.04 & 0.36 \\
\hline $\mathrm{Re}_{2} \mathrm{O}_{7}$ & 0.06 & 0.06 & 0.08 & 0.09 & 0.13 & 0.06 \\
\hline Total & 99.89 & & 99.69 & & 98.58 & \\
\hline
\end{tabular}

bending $\left(\mathrm{v}_{4}\right)$. Raman spectra of the crystals thus confirm that the reported crystals are a Re-sodalite phase.

Raman spectra of the silicate glass does not reveal any Re-related peak. It was previously reported that peaks of perrhenate only become distinguishable from the background glass signal at contents of several thousands of $\mu \mathrm{g} / \mathrm{g}$ [35]. Therefore, our failure to detect any peaks related to $\mathrm{Re}$ is consistent with the chemical analysis showing Re contents equal to $\sim 1500 \mu \mathrm{g} / \mathrm{g}$ at maximum.

\section{SN Applied Sciences}




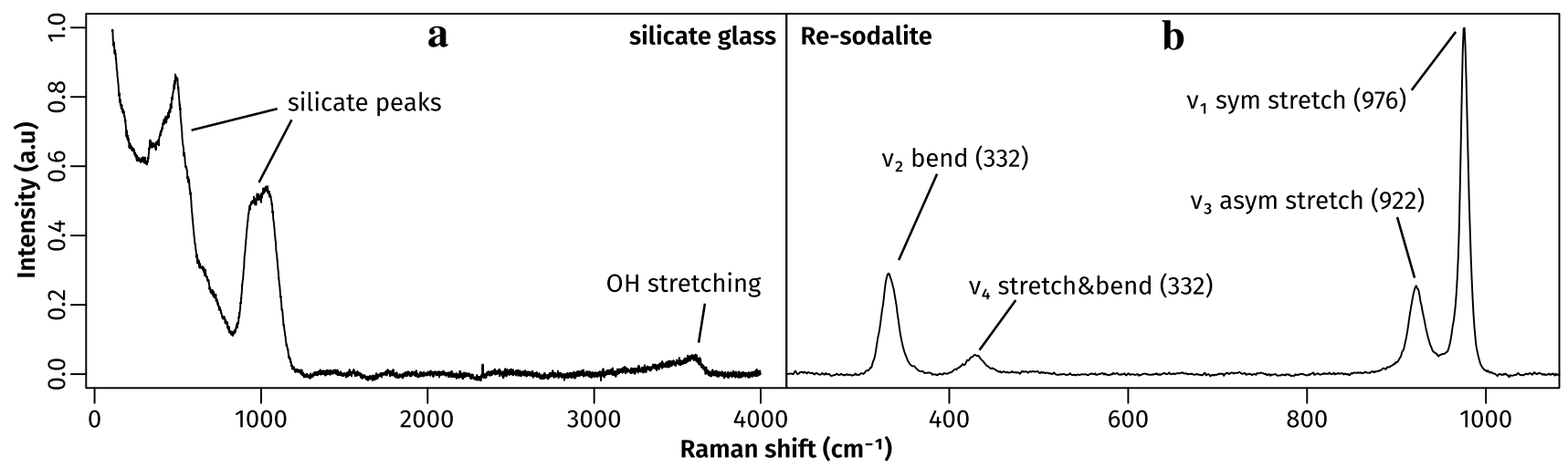

Fig. 3 Raman spectra of experimental products in experiment D1906-103. a silicate glass b Re-sodalite. Each spectrum is an average of two separate spectra

\section{Discussion}

The presence of Re-sodalite in experiments run for $19 \mathrm{~h}$ at $1100^{\circ} \mathrm{C}$ indicates that it is a thermodynamically stable phase at these conditions and melt composition. Rhenium was sourced from the Re strip placed in the capsules, and as such it was expected that sodalites would be more common adjacent to the strip. Surprisingly, Re-sodalite was found exclusively as crusts on metal surfaces regardless of the position in the capsule. This is in contrast with nepheline and magnetite that are distributed homogeneously throughout the capsule. The Re-sodalite crusts appear identical whether they were on Pt, Pt-Rh, Ag-Pd, and even on the Re metal itself. This indicates that the noble metals catalysed the Re-sodalite crystallisation.

The silicate glass contains up to $1000 \mathrm{ppm}$ of Re, whereas the Re-sodalite contain $\sim 25 \%$ Re. This represents a 2500-fold increase in Re concentration in the solid phase relative to the liquid. This confirms the exceptional potential of sodalite to extract Re from silicate melts (and by analogy, Tc [15]). Most nuclear waste glasses are not as sodic as our starting materials and contain abundant $\mathrm{B}_{2} \mathrm{O}_{3}$ (e.g., [36]), which may explain the lack of sodalite crystallisation even though the glasses are commonly prepared in noble metal crucibles. This indicates that Re-sodalite may not be a thermodynamically stable phase in these melts. Therefore, their retention (e.g., [15]) is likely promoted by slow dissolution kinetics of Re-sodalite in the liquid, which does not proceed to completion in the rapid heating and subsequent quenching during nuclear waste vitrification.

As mentioned above, our runs were buffered close to the $\mathrm{Re}-\mathrm{ReO}_{2}$ oxygen fugacity buffer, in which the oxidation state of Re in the oxide is 4+. Yet, sodalite contains $\mathrm{Re}^{7+}$ in perrhenate. The higher oxidation state is an example of the general tendency of metals to adopt higher oxidation states with $\mathrm{Na}$ or other basic cations as next-nearest neighbours, as generally found in silicate melts [37, 38].
This effect has been described from solids such as aegirine ( $\mathrm{NaFe}^{3+} \mathrm{Si}_{2} \mathrm{O}_{6}$ [39]), dyrnaesite-( $\left.\mathrm{La}\right)\left(\mathrm{Na}_{8} \mathrm{Ce}^{4+} \mathrm{La}_{2} \mathrm{P}_{6} \mathrm{O}_{24}[40\right.$, $41]$ ), and sodic amphiboles (riebeckite and arfvedsonite [42]). Likewise, the oxidation state of Re in the glass is expected to be dominated by $\operatorname{Re}^{6+}$ and $\operatorname{Re}^{7+}[32,43-45]$. Remarkably, these higher oxidation states of Re are stable in equilibrium with metallic $\mathrm{Re} . \mathrm{NaReO}_{4}$ has been observed as a stable phase at conditions similar to those of our experiments [44,46,47], but was not observed in the present case. However, as our samples were prepared by water-lubricated polishing, any exposed perrhenate salts would immediately dissolve. The formation of perrhenate salts on the surface of our polished sections may have resulted from remobilisation of crystalline $\mathrm{NaReO}_{4}$ through cracks in the glass during sample preparation [46].

\section{Conclusions}

Crystallisation of Re-sodalite from a sodic Fe-bearing aluminosilicate melt was observed at high temperature and high pressure. Crystallisation happened to be catalysed by noble metals and alloys during the experiments. Resodalite can thus be a stable phase in Na-rich silicate melts in equilibrium with Re-bearing alloys at high pressure and high temperature. Therefore, in addition to the hydrothermal path previously presented [16], high pressure and high temperature experiments are another path to Resodalite synthesis. Furthermore, the experiments suggest that the presence of a noble metal catalysers in Na-rich silicate melts may be another way to stabilise Re-sodalite to higher temperatures, inhibiting through this way Re (and by analogy, Tc) volatilisation during vitrification processes, or increased stability during glass alteration $[48,49]$.

Acknowledgements This work was supported by Australian Research Council grant FL130100066 to Hugh O'Neill. We acknowledge the 
facilities and technical assistance of Jeff Chen at Microscopy Australia, Centre for Advanced Microscopy, ANU.

\section{Compliance with ethical standards}

Conflicts of interest We declare no conflicts of interest.

\section{References}

1. Hassan I, Grundy HD (1984) The crystal structures of sodalitegroup minerals. Acta Crystallogr B 40(1):6-13. https://doi. org/10.1107/S0108768184001683

2. Pan L, Liu W, Chen W, Yan K, Yang H, Yu J (2016) Crystal structure and band gap studies of sodalite: experimental and calculated results. J Mol Struct 1106:59-63. https://doi.org/10.1016/j.molst ruc.2015.10.045

3. Tomisaka T, Eügster HP (1968) Synthesis of the sodalite group and subsolidus equilibria in the sodalite-noselite system. Miner J 5(4):249-275. https://doi.org/10.2465/minerj1953.5.249

4. Murshed MM, Gesing TM (2007) Isomorphous gallium substitution in the alumosilicate sodalite framework: synthesis and structural studies of chloride and bromide containing phases. Z Kristallogr 222(7):341. https://doi.org/10.1524/ zkri.2007.222.7.341

5. Johnson GM, Mead PJ, Weller MT (2000) Synthesis of a range of anion-containing gallium and germanium sodalites. Microporous Mesoporous Mater 38(2):445-460. https://doi.org/10.1016/ S1387-1811(00)00169-4

6. Nakazawa T, Kato H, Okada K, Ueta S, Mihara M (2000) lodine immobilization by sodalite waste form. MRS Online Proc Libr 663:51. https://doi.org/10.1557/PROC-663-51

7. Maddrell E, Gandy A, Stennett M (2014) The durability of iodide sodalite. J Nucl Mater 449(1):168-172. https://doi.org/10.1016/j. jnucmat.2014.03.016

8. Zhang S, Cui X, L-p Liu, W-p Zhang (2010) A novel chemosynthetic method for the production of nitrate sodalite. Mater Lett 64(24):2667-2669. https://doi.org/10.1016/j.matlet.2010.08.075

9. Borhade A, Dholi A (2013) Synthesis and crystal structure of chlorate-enclathrated in aluminogermanate sodalite $\mathrm{Na}_{8}\left[\mathrm{AlGeO}_{4}\right]_{6}\left(\mathrm{ClO}_{3}\right)_{2}$. Microporous Mesoporous Mater 31(2):246252. https://doi.org/10.2478/s13536-012-0096-y

10. Moroney LM, Shanmugam S, Langdon AG (1988) The chemistry and catalytic properties of transition metal oxyanions in sodalite cages. In: Bibby DM, Chang CD, Howe RF, Yurchak S (eds) Studies in surface science and catalysis, vol 36. Elsevier, Amsterdam, pp 603-607. https://doi.org/10.1016/s0167-2991(09)60556-5

11. Schliesser J, Lilova K, Pierce EM, Wu L, Missimer DM, Woodfield BF, Navrotsky A (2017) Low temperature heat capacity and thermodynamic functions of anion bearing sodalites $\mathrm{Na}_{8} \mathrm{Al}_{6} \mathrm{Si}_{6} \mathrm{O}_{24} \mathrm{X}_{2}$ $\left(\mathrm{X}=\mathrm{SO}_{4}, \mathrm{ReO}_{4}, \mathrm{Cl}\right.$, I). J Chem Thermodyn 114:14-24. https://doi. org/10.1016/j.jct.2017.05.035

12. Dickson JO, Harsh JB, Flury M, Lukens WW, Pierce EM (2014) Competitive incorporation of perrhenate and nitrate into sodalite. Environ Sci Technol 48(21):12851-12857. https://doi. org/10.1021/es503156v

13. Dickson JO, Harsh JB, Flury M, Pierce EM (2015) Immobilization and exchange of perrhenate in sodalite and cancrinite. Microporous Mesoporous Mater 214:115-220. https://doi.org/10.1016/j. micromeso.2015.05.011

14. Dickson JO, Harsh JB, Lukens WW, Pierce EM (2015) Perrhenate incorporation into binary mixed sodalites: the role of anion size and implications for technetium-99 sequestration. Chem Geol 395:138-143. https://doi.org/10.1016/j.chemgeo.2014.12.009
15. Luksic SA, Riley BJ, Parker KE, Hrma P (2016) Sodalite as a vehicle to increase Re retention in waste glass simulant during vitrification. J Nucl Mater 479:331-337. https://doi.org/10.1016/j.jnucm at.2016.07.002

16. Mattigod SV, Peter McGrail B, McCready DE, Wang L-Q, Parker KE, Young JS (2006) Synthesis and structure of perrhenate sodalite. Microporous Mesoporous Mater 91(1):139-144. https://doi. org/10.1016/j.micromeso.2005.11.025

17. Pierce EM, Lilova K, Missimer DM, Lukens WW, Wu L, Fitts J, Rawn C, Huq A, Leonard DN, Eskelsen JR, Woodfield BF, Jantzen CM, Navrotsky A (2017) Structure and thermochemistry of perrhenate sodalite and mixed guest perrhenate/pertechnetate sodalite. Environ Sci Technol 51(2):997-1006. https://doi. org/10.1021/acs.est.6b01879

18. Pegg IL (2015) Behavior of technetium in nuclear waste vitrification processes. J Radioanal Nucl Chem 305(1):287-292. https:// doi.org/10.1007/s10967-014-3900-9

19. Jin T, Kim D, Tucker AE, Schweiger MJ, Kruger AA (2015) Reactions during melting of low-activity waste glasses and their effects on the retention of rhenium as a surrogate for technetium-99. J Non-Cryst Solids 425:28-45. https://doi.org/10.1016/j. jnoncrysol.2015.05.018

20. Pierce EM, Lukens WW, Fitts JP, Jantzen CM, Tang G (2014) Experimental determination of the speciation, partitioning, and release of perrhenate as a chemical surrogate for pertechnetate from a sodalite-bearing multiphase ceramic waste form. Appl Geochem 42:47-59. https://doi.org/10.1016/j.apgeo chem.2013.12.017

21. Xu K, Pierce DA, Hrma P, Schweiger MJ, Kruger AA (2015) Rhenium volatilization in waste glasses. J Nucl Mater 464:382-388. https://doi.org/10.1016/j.jnucmat.2015.05.005

22. Anenburg M, Mavrogenes JA (2016) Experimental observations on noble metal nanonuggets and Fe-Ti oxides, and the transport of platinum group elements in silicate melts. Geochim Cosmochim Acta 192:258-278. https://doi.org/10.1016/j. gca.2016.08.010

23. Çubukçu HE, Ersoy O, Aydar E, Çakir U (2008) WDS versus silicon drift detector EDS: a case report for the comparison of quantitative chemical analyses of natural silicate minerals. Micron 39(2):88-94. https://doi.org/10.1016/j.micron.2006.11.004

24. Reed SJB (2005) Electron microprobe analysis and scanning electron microscopy in geology, 2nd edn. Cambridge University Press, Cambridge. https://doi.org/10.1017/cbo9780511610561

25. Le Losq C (2018) Rampy: a Python library for processing spectroscopic (IR, Raman, XAS...) data. Zenodo, Geneva. https://doi. org/10.5281/zenodo.1168730

26. Le Losq C, Neuville DR, Moretti R, Roux J (2012) Determination of water content in silicate glasses using Raman spectrometry: implications for the study of explosive volcanism. Am Mineral 97(5-6):779-790. https://doi.org/10.2138/am.2012.3831

27. Di Genova D, Sicola S, Romano C, Vona A, Fanara S, Spina L (2017) Effect of iron and nanolites on Raman spectra of volcanic glasses: a reassessment of existing strategies to estimate the water content. Chem Geol 475:76-86. https://doi.org/10.1016/j. chemgeo.2017.10.035

28. Brousse R, Varet J, Bizouard H (1969) Iron in the minerals of the sodalite group. Contrib Miner Pet 22(3):169-184. https://doi. org/10.1007/bf00387951

29. Ravikumar RVSSN, Chandrasekhar AV, Yamauchi J, Reddy YP, Rao PS (2005) Tetrahedral site of iron in natural mineral sodalite. Radiat Eff Defects Solids 160(3-4):109-115. https://doi. org/10.1080/10420150500132364

30. Taylor D (1967) The sodalite group of minerals. Contrib Miner Pet 16(2):172-188. https://doi.org/10.1007/bf00372796

31. Pownceby MI, O'Neill HSC (1994) Thermodynamic data from redox reactions at high temperatures. IV. Calibration of the 
$\mathrm{Re}-\mathrm{ReO}_{2}$ oxygen buffer from $\mathrm{EMF}$ and $\mathrm{NiO}+\mathrm{Ni}-\mathrm{Pd}$ redox sensor measurements. Contrib Miner Pet 118(2):130-137. https:// doi.org/10.1007/bf01052864

32. Ertel W, O'Neill HSC, Sylvester PJ, Dingwell DB, Spettel B (2001) The solubility of rhenium in silicate melts: implications for the geochemical properties of rhenium at high temperatures. Geochim Cosmochim Acta 65(13):2161-2170. https://doi. org/10.1016/s0016-7037(01)00582-8

33. Mallmann G, O'Neill HSC (2007) The effect of oxygen fugacity on the partitioning of Re between crystals and silicate melt during mantle melting. Geochim Cosmochim Acta 71(11):2837-2857. https://doi.org/10.1016/j.gca.2007.03.028

34. Le Losq C, Cicconi MR, Greaves GN, Neuville DR (2019) Silicate glasses. In: Musgraves JD, Hu J, Calvez L (eds) Handbook of glass. Springer, New York. https://doi.org/10.1007/978-3-319-93728-1

35. Gassman PL, McCloy JS, Soderquist CZ, Schweiger MJ (2014) Raman analysis of perrhenate and pertechnetate in alkali salts and borosilicate glasses. J Raman Spectrosc 45(1):139-147. https://doi.org/10.1002/jrs.4427

36. Plodinec MJ (2000) Borosilicate glasses for nuclear waste imobilisation. Glass Technol 41(6):186-192

37. Duffy JA (1993) A review of optical basicity and its applications to oxidic systems. Geochim Cosmochim Acta 57(16):3961-3970. https://doi.org/10.1016/0016-7037(93)90346-X

38. Giuli G, Alonso-Mori R, Cicconi MR, Paris E, Glatzel P, Eeckhout SG, Scaillet B (2012) Effect of alkalis on the Fe oxidation state and local environment in peralkaline rhyolitic glasses. Am Mineral 97(2-3):468-475. https://doi.org/10.2138/am.2012.3888

39. Markl G, Marks MAW, Frost BR (2010) On the controls of oxygen fugacity in the generation and crystallization of peralkaline melts. J Petrol 51(9):1831-1847. https://doi.org/10.1093/petro logy/egq040

40. Balić-Žunić $T$ (2017) The crystal structure of the new mineral dyrnaesite-(La), $\mathrm{Na}_{8} \mathrm{Ce}^{\mathrm{IV}} \mathrm{REE}_{2}\left(\mathrm{PO}_{4}\right)_{6}$. Miner Mag 81(1):199-208. https://doi.org/10.1180/minmag.2016.080.096

41. Rønsbo JG, Balić-Žunić T, Petersen OV (2017) Dyrnaesite-(La) a new hyperagpaitic mineral from the llímaussaq alkaline complex, South Greenland. Miner Mag 81(01):103-111. https://doi. org/10.1180/minmag.2016.080.075
42. Ernst WG (1962) Synthesis, stability relations, and occurrence of riebeckite and riebeckite-arfvedsonite solid solutions. J Geol 70(6):689-736

43. McCloy JS, Riley BJ, Goel A, Liezers M, Schweiger MJ, Rodriguez CP, Hrma P, Kim D-S, Lukens WW, Kruger AA (2012) Rhenium solubility in borosilicate nuclear waste glass: implications for the processing and immobilization of technetium-99. Environ Sci Technol 46(22):12616-12622. https://doi.org/10.1021/es302 $734 y$

44. Goel A, McCloy JS, Windisch CF Jr, Riley BJ, Schweiger MJ, Rodriguez Carmen P, Ferreira JMF (2013) Structure of rhenium-containing sodium borosilicate glass. Int J Appl Glass Sci 4(1):42-52. https://doi.org/10.1111/ijag.12003

45. Lukens WW, McKeown DA, Buechele AC, Muller IS, Shuh DK, Pegg IL (2007) Dissimilar behavior of technetium and rhenium in borosilicate waste glass as determined by X-ray absorption spectroscopy. Chem Mater 19:559-566. https://doi.org/10.1021/ $\mathrm{cm} 0622001$

46. Riley BJ, McCloy JS, Goel A, Liezers M, Schweiger MJ, Liu J, Rodriguez CP, Kim D-S (2013) Crystallization of rhenium salts in a simulated low-activity waste borosilicate glass. J Am Ceram Soc 96(4):1150-1157. https://doi.org/10.1111/jace.12280

47. Atzesdorfer A, Range K-J (1995) Sodium metaperrhenate, $\mathrm{NaReO}_{4}$ : high pressure synthesis of single crystals and structure refinement. Z Naturforsch, B 50(9):1417-1418. https://doi. org/10.1515/znb-1995-0921

48. Buechele AC, McKeown DA, Lukens WW, Shuh DK, Pegg IL (2012) Tc and Re behavior in borosilicate waste glass vapor hydration tests II. J Nucl Mater 429:159-165. https://doi.org/10.1016/j. jnucmat.2012.05.032

49. Luksic SA, Riley BJ, Schweiger MJ, Hrma P (2015) Incorporating technetium in minerals and other solids: a review. J Nucl Mater 466:526-538. https://doi.org/10.1016/j.jnucmat.2015.08.052

Publisher's Note Springer Nature remains neutral with regard to jurisdictional claims in published maps and institutional affiliations. 